\title{
UTILIZATION OF DIGESTATE OBTAINED FROM METHANE FERMENTATION OF CHICKEN MANURE
}

\author{
Wojciech CZEKAŁA ${ }^{\mathbf{1}}$, Jacek DACH ${ }^{\mathbf{1}}$, Andrzej LEWICKI ${ }^{\mathbf{1}}$, \\ Katarzyna GAJEWSKA ${ }^{1}$, Żaneta STASZAK ${ }^{2}$ \\ ${ }^{1}$ Poznan University of Life Sciences, POLAND \\ ${ }^{2}$ Poznan University of Technology, POLAND \\ E-mail of corresponding author: wojciech@up.poznan.pl
}

Keywords: biogas, digestate, chicken manure, waste management

\begin{abstract}
Since 2012, Poland is the European leader in poultry production and one of world's key exporters of poultry meat. Poultry production is directly related with presence of droppings. Depending on the type of breeding, a by-product can be droppings or manure. The most popular solution of utilizing chicken droppings and manure is using them as fertilizer. Considering issues related with environmental protection, more often alternative methods are searched for. One of them is utilizing the discussed substrate in the process of methane fermentation. Products of the process will be biogas and digestate. The aim of the work was to present possibilities of utilizing the digestate obtained in the process of fermentation of chicken manure.
\end{abstract}

\section{INTRODUCTION}

Chicken droppings and manure are waste materials which are strenuous for human life and the environment (Hussein et al., 2017). The greatest threats are related with emission of detrimental gases (mainly ammonia), emission of leachates to soil, ground and surface waters, and with microbiological hazards. One of preferred ways of the waste management is anaerobic decomposition of them (Czekała et al., 2015). Another method of the waste management is extrusion cooking technique (Guz at al., 2011, Oniszczuk at al., 2015, Oniszczuk at al., 2016). Application of this technique allows to manage a lot of agriculture waste materials (Obidziński 2014., Obidziński et al., 2016., Oniszczuk et al., 2013)

\section{METHANE FERMENTATION AS A WAY TO UTILIZATION POULTRY WASTE MATERIALS}

Methane fermentation has a large potential in utilization of agricultural and food wastes (Czekała et al., 2017). Strongly intensified poultry production is related with production of waste, which need to be utilized (Burra et al., 2016). Waste management is an obligation of producers active in the field of animal breeding. As a result, the process of biodegradation in controlled conditions seems to be a solution meeting this criterion and offering additional benefits for producers as well as the environment (Gizińska-Górna et al., 2016; Kowalczyk-Juśko et al., 2015). Using manure for biogas aims is related with an effective limitation of emission of harmful compounds to the atmosphere, which are released during its collection or use in the form of a raw fertilizer, as well as elimination of a potential sanitary hazard (Hagos et al, 2017).

The process of methane fermentation consists in an anaerobic decomposition of organic matter with the use of anaerobic microorganisms. A product of the fermentation is biogas, composed mainly of methane (50-75\%), carbon dioxide (25-50\%), and trace amounts of hydrogen sulphide, hydrogen, nitrogen, oxygen, and carbon monoxide. As far as the process efficiency is concerned, chicken manure is a substrate strongly susceptible to fermentation, due to e.g. a high content of albuminoids and organic dry matter - 63-80\% 
of the mass. Chicken manure has also relatively high biogas efficiency, 250-450 $\mathrm{m}^{3} \cdot \mathrm{Mg}^{-}$

${ }^{1}$ of the organic dry matter and content of methane in biogas reach $60 \%$ by volume.

However, the use of chicken manure as a substrate for fermentation is related with a significant technological challenge, i.e. a high content of nitrogen. Bacteria of the methanogenesis stage are very sensible to its excessive amount. A high content of nitrogen can act in an inhibited way on the process of methanogenesis. Nitrogen in the amount from $1,5-3 \mathrm{~g} \cdot \mathrm{dm}^{-3}$, at proper $\mathrm{pH}$ can be an inhibitor of the process, while at the concentration over $3,7 \mathrm{~g} \cdot \mathrm{dm}^{-3}$, nitrogen has killing effect on methane bacteria. The possibility of an efficient fermentation process is enabled by using a co-substrate which is rich in organic carbon.

\section{DIGESTED PULP AS A PRODUCT OF METHANE FERMENTATION}

Unskilful use of chicken manure in the form of a raw fertilizer is detrimental to the environment. It is necessary to develop a solution enabling its safe and effective use. Production of biogas through methane fermentation brings benefits resulting not only from efficient obtaining of gas (Deepanraj et al., 2017). It is possible also a by-product of the process, i.e. a digested pulp, which can be used as a valuable fertilizer (Hung et al., 2017). A strong concentration of minerals, elimination of odour substances, as well as pulp's $\mathrm{pH}$ at the level of 8 , make it can be a strong competition for chemical fertilizers currently available on the market.

Digestate is a by-product of the process of methane fermentation, which is a digested residue of the substrate used in the process. Usually, it makes about $90 \%$ of mass of the substrate feed to a reactor. In case of a biogas plant of the power of $0,5 \mathrm{MW}$, there is produced about $10000 \mathrm{Mg}$ of digestate mass. This value can be significantly diversified, depending on used substrates. Counter to the common belief, digestate is not only a waste that needs to be utilized. It has a large potential as far as fertilizing and energy is concerned. Digestate is characterised by a high concentration of nitrogen, phosphorus, potassium, which are most essential for plants as far as fertilizing is concerned.

A conversion of complex compounds to inorganic compounds contributes to a reduction of pathogens or seeds of weeds contained in the digestate. In the course of the process of mesophilic fermentation, majority of viruses, bacteria and other organisms present in raw manure is being neutralised. On the other hand, in the process of thermophilic fermentation, all pathogenic organisms are neutralised. Thanks to the fermentation process, the pulp becomes a safe and environmental friendly fertilizer, in comparison to the raw manure.

Storage of natural fertilizers has a significant influence on uncontrolled emission of methane and ammonia (Dinuccio et al., 2012). An advantage of the digestate coming from natural fertilizers is a reduction of gas emissions, including methane, which is one of the most strenuous compounds of animal production. Thus, using manure for biogas aims will be related not only with a reduction of the methane emission, but also depriving a substance of odour compounds.

Raw digestate is characterised with a relatively high hydration. The content of water in the substance is $90-95 \%$. Apart from the used process technology, in case of the utilized chicken manure in the fermentation, also a species of poultry has an influence on the level of the pulp hydration. Usually, the $\mathrm{pH}$ of the digestate ranges from 8 to 8,5 , thus, it is reasonable to use such form of fertilizing in soils in which a strong acidification is present. 
Using the digestate in the form of a fertilizer of full value is related with its proper processing, consisting mainly in the material dehydration.

\section{DIGESTED PULP MANAGEMENT}

According to the Waste Management Act of 14.12.2012 (Journal of Laws 2013, item 21), the following forms of recovery are distinguished:

- R1 process - „using as a fuel or other source of energy”,

- R3 process - ,recycling or recovery of organic matter, which are not used as dissolvent (including composting and other biological transforming processes)",

- R10 process - ,processing on the soil surface offering benefits for agriculture or an improvement of the environment condition".

Each recovery method has individual requirements that need to be met in order that a process could be legally regarded as properly conducted. After conducting a process, a producer of the digestate has a chance to apply for a permit of marketing of products supporting growing. However, in order this was possible, requirements stated in the Article 4 of the Act on Fertilizers and Fertilizer Application and the Regulation of the Ministry of Agriculture and Rural Development of 18.06.2008 on execution of some regulations concerning fertilizers and fertilizer application (Journal of Laws item 119, point 765 ) should be met. 765 .

This record obligates producers to satisfy a complex revision procedure and conducting test of a potential fertilizer with regard to a possible usability of fertilizing soil and plant. It is also indispensable to obtain positive results of tests of the pulp with regard to the presence of intestinal parasites and pathogenic bacteria, which exclude their presence in the obtained fertilizer.

Whole digestate pulp should initially undergo the process of dehydration or drying in order to decrease the content of water, and its volume as a result. A high hydration will result not only in problems with efficient storage but mainly with the possibility of further utilisation.

The reduction of water in digestate can be obtained using one of below methods:

- mechanical, using centrifuges or presses,

- thermal and pressure, consisting in evaporating water,

- physical, in which dehydration is done due to sedimentation or membrane filtration.

Each of the above solutions shall be characterized by different efficiencies and energy consumption, thus, it is necessary to select a solution that the whole processing process was optimised in the most possible way as far as energetic and economic issues are concerned.

After a separation into fractions, the post-fermentation pulp can be used in numerous ways. Solid fraction has a structure similar to fresh compost and is greatly deprived of pathogens. This material has dry matter at the level of $25-30 \%$ and it is loose. It can be mainly used as a fertilizer or an agent for improving the soil quality. On the other hand, liquid fraction is characterised by a low content of dry matter, usually amounting up to $5 \%$. Liquid fraction can be used as a fertilizer or used in the process of fermentation for a possible dilution of the substrate. 


\section{CONCLUSION}

Strongly developed poultry production obligates Poland to solve the issue of the utilisation of large-scale post-production wastes. Due to their good biogas features, there is a potential of their efficient utilisation, at the same time having benefits resulting from the biogas production. A high content of ammonia nitrogen present in chicken excrements forms a certain type of a technological barrier, potentially hazardous to the fermentation process. It is necessary to develop a technology enabling a co-fermentation of chicken manure with another substrate, at the same time maintaining high biogas efficiencies, or developing a new, innovative, and economically efficient technology of single-substrate fermentation. The pulp obtained during the process of methane fermentation has also a high fertilizing potential thanks to a strong concentration of minerals and organic components. Properly processes digestate has a chance to become a fertilizer of full value, being a serious competition to artificial fertilizers.

\section{ACKNOWLEDGMENT}

This work was funded by the National Centre for Research and Development (NCBR) in programme LIDER No LIDER/189/l-6/14/NCBR/2015.

\section{REFERENCES}

Burra, K.G., Hussein M.S., Amano R.S., Gupta A.K. (2016). Syngas evolutionary behavior during chicken manure pyrolysis and air gasification. Applied Energy, 181, 408-415.

Czekała, W., Dach, J., Ludwiczak, A., Przybylak, A., Boniecki, P., Koszela, K., Zaborowicz, M., Przybył, K., Wojcieszak, D., Witaszek, K. (2015). The use of image analysis to investigate C:N ratio in the mixture of chicken manure and straw. Proc. SPIE. 9631, Seventh International Conference on Digital Image Processing (ICDIP 2015), 963117.doi: 10.1117/12.2197041.

Czekała, W., Dach, J., Dong, R., Janczak, D., Malińska, K., Jóźwiakowski, K., Smurzyńska, A., Cieślik, M. (2017). Composting potential of the solid fraction of digested pulp produced by a biogas plant. Biosystems Engineering, 160, 25-29.

Deepanraj B., Sivasubramanian V., Jayaraj S. (2017). Effect of substrate pretreatment on biogas production through anaerobic digestion of food waste. International Journal of Hydrogen Energy, In Press.

Dinuccio E., Gioelli F., Balsari P., Dorno N. (2012). Ammonia losses from the storage and application of raw and chemo-mechanically separated slurry. Agriculture, Ecosystems \& Environment, Volume 153, 1623

Gizińska-Górna, M., Czekała, W., Jóźwiakowski, K., Lewicki, A., Dach, J., Marzec, M., Pytka, A., Janczak, D., Kowalczyk-Juśko, A., Listosz, A. (2016). The possibility of using plants from hybrid constructed wetland wastewater treatment plants for energy purposes. Ecological Engineering, 95, 534541.

Hagos K., Zong J., Li D., Liu C., Lu X. (2017). Anaerobic co-digestion process for biogas production: Progress, challenges and perspectives. Renewable and Sustainable Energy Reviews, 76, 1485-1496.

Hung C.Y., Tsai W.T., Chen J.W., Lin Y.Q., Chang Y.M. (2017). Characterization of biochar prepared from biogas digestate. Waste Management, 66, 53-60

Hussein, M.S., Burra, K.G., Amano, R.S., Gupta, A.K. (2017). Effect of oxygen addition in steam gasification of chicken manure. Fuel, 189, 428-435.

Kowalczyk-Juśko, A., Kościk, B., Jóźwiakowski, K., Marczuk, A., Zarajczyk, J., Kowalczuk, J., Szmigielski, M., Sagan, A. (2015). Effects of biochemical and thermochemical conversion of sorghum biomass to usable energy. Przemyst Chemiczny, 94/10, 1838-1840.

Obidzinski S. (2014). Utilization of post-production waste of potato pulp and buckwheat hulls in the form of pellets. Polish Journal of Environmental Studies, 23/4, 1391-1395. 
Obidziński S., Piekut J., Dec D. (2016). The influence of pulp content on the properties of pellets from buckwheat hulls. Renewable Energy, 87, 289-297.

Oniszczuk T., Pilawka R. (2013). Effect of cellulose fibers on thermal strength of thermoplastic starch. Przemyst Chemiczny, 92/2, 265-269.

Guz L., Sopinska A., Oniszczuk T., (2011). Effect of Echinacea purpurea on growth and survival of guppy (Poecilia reticulata) challenged with Aeromonas bestiarum, Aquaculture Nutrition, 17/6, 695-700.

Oniszczuk T., Wójtowicz A., Mościcki L., Mitrus M., Kupryaniuk K., Kusz A., Bartnik G. (2016). Effect of natural fibres on the mechanical properties of thermoplastic starch. International Agrophysics, 30/2, 211-218.

Oniszczuk T., Mitrus M., Wójtowicz A., Mościcki L. (2015). Addition of bark in the production of the starch-based composites. Przemyst Chemiczny, 94/10, 1748-1751. 